\title{
Two observations of pumice levels from the west coast of Spitsbergen
}

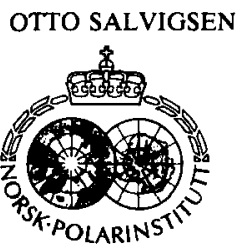

During the summer of 1983 pumice was observed on raised beaches in two localities on the west coast of Spitsbergen. This is an area where pumice
Salvigsen, O. 1984: Two observations of pumice levels from the west coast of Spitsbergen. Polar Research 2 n.s., $115-116$.

Otto Salvigsen, Norsk Polarinstitutt, Rolfstangveien 12, 1330 Oslo Lufthavn, Norway.

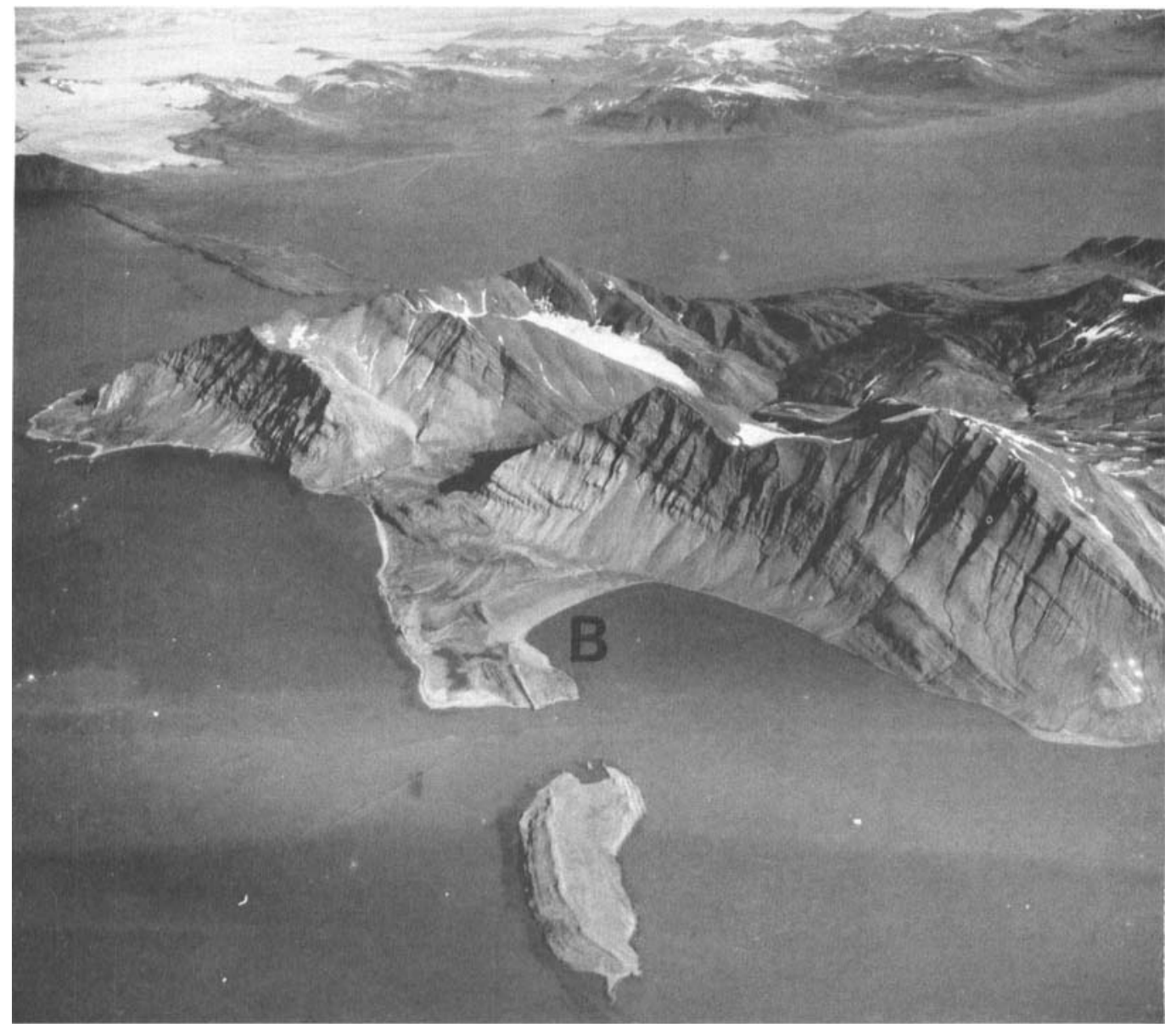

Fig. 1. Midterhuken between Van Mijenfjorden and Van Keulenfjorden where pumice is abundant in two major zones on the raised beach ridges in Van Keulenhamna (B). Photo: Norsk Polarinstitutt S 363178.

has not been reported (Salvigsen 1984), and a preliminary note should therefore be of interest. A. - Pumice pieces were observed in three 
places between Russekeila and Kapp Linné in the outermost part of Isfjorden. Only 5-10 pieces were observed in each place, and their elevations, between 8.9 and $9.9 \mathrm{~m}$, were determined by precise leveling.

B. - During a $1 \frac{1}{2}$ hours stay in Van Keulenhamna, between Van Keulenfjorden and Van Mijenfjorden, a traverse was examined covering a 20 to $30 \mathrm{~m}$ wide swath from the shore to the highest point of Strandvollsletta (meaning beach ridge plain) (Fig. 1). Three levels of pumice were found. A quick leveling with a hand-held instrument and counting of pumice pieces gave the following result:

1. 5 pieces at approximately $4.5 \mathrm{~m}$ above sea level.

2. 33 pieces between 6.7 and $7.7 \mathrm{~m}$ above sea level.

3. 96 pieces between 10.2 and $11.5 \mathrm{~m}$ above sea level.

Many of the pieces in the highest level were large, about $15 \mathrm{~cm}$ in diameter. This level and the pum- ice level in outer Isfjorden can be correlated with the main pumice level in Svalbard with an age of about 6500 years B.P.

The new observations indicate that large amounts of pumice must have drifted ashore also on the western coast of Svalbard during the Holocene. Where conditions have been favourable for preservation of pumice, pumice levels can be found and be useful for correlation of raised shorelines. Pumice is generally found in two major zones in inner Isfjorden (Salvigsen 1984), and the observations from Van Keulenhamna indicate that the same pattern exists on the west coast of Spitsbergen.

\section{Reference}

Salvigsen, O. 1984: Occurrence of pumice on raised beaches and Holocene shoreline displacement in the inner Isfjorden area, Svalbard. Polar Research 2 n.s., 107-113. 